\title{
RESOURCE-RELATED SPATIAL PATTERNS OF SEARCH IN THE ANT FORMICA SCHAUFUSSI: A FIELD STUDY. ${ }^{1}$
}

\author{
BY
}

\author{
JAMES F. A. TRANiEllo \\ ANDREA J. KOZOL \\ Michael A. FourNier \\ Boston University \\ Department of Biology \\ 5 Cummington Street \\ Boston, MA 02215
}

\section{INTRODUCTION}

Within at least some groups of ant species, the colony-level and individual search tactics of workers are correlated with the types of food resources they collect (reviewed in Traniello, 1989). In two omnivorous formicine species, Cataglyphis bicolor and Formica schaufussi, foragers differ in their tendency to return to and search at the site of a prior food find (Schmid-Hempel, 1984; Traniello, 1988). In F. schaufussi, the spatiotemporal characteristics of a forager's search path appear to be related to the spatiotemporal pattern of the distribution of carbohydrate (homopteran honeydew; fruits; plant sap, eg.) and protein (dead arthropods) food sources collected by a colony (Traniello et al. 1991).

Local search behavior can be induced in a $F$. schaufussi forager by offering a single reward of either carbohydrate (a crop load of a sucrose solution) or protein (a dead insect) food, and the search pattern at the site of the food find can be recorded on videotape and subsequently analyzed. In the laboratory we have discriminated among search paths using motion analysis techniques (Fourcassié and Traniello, $1992 \mathrm{a}, \mathrm{b}$ ) and fractal analysis (Fourcassié et al. 1992). These studies demonstrate that carbohydrate- and protein-stimulated search patterns differ in their spatial and temporal properties. Here we extend our studies by examining the characteristics and correlates of carbohydrate- and protein-stimulated search

\footnotetext{
${ }^{1}$ Dedicated to Professor William L. Brown, Jr., on the occasion of his retirement. Manuscript received 10 June 1992
} 
patterns in the field, focusing on the effects of experience and seasonal changes in colony food requirements.

\section{Materials AND Methods}

Formica schaufussi is a common open-field ant that nests in soil. Study colonies were located at the Concord Field Station of Harvard University in Concord, Massachusetts. Workers tend homopterans for their carbohydrate secretions and feed on plant sap directly and also forage for arthropod prey, chiefly dead insects, which compose the protein component of the diet. Studies were conducted from May-September 1987 on two colonies. On average, two to three foragers were studied per colony per day. Both colonies produced alates during the first week of July.

To study the spatial pattern and modifiability of search, either a single crop load of $1 \mathrm{M}$ sucrose or a single insect (a termite, [Reticulitermes flavipes] approximately $3 \mathrm{mg}$ in weight) was offered to a forager that had departed from the nest and traveled roughly 1-2 $\mathrm{m}$. The majority of foragers encountered the experimentally offered food source while traveling to a site to search for food as opposed to encountering food while showing local search behavior (Traniello 1988; Traniello et al. 1991).

Search behavior was recorded following the collection of either a protein or carbohydrate reward and the return from the nest to the reward site. While collecting their first food load foragers were marked with a spot of enamel paint to permit subsequent recognition. To characterize a search pattern the average distance of a searching worker from the reward site was measured by taking a fix of the forager's position every $10 \mathrm{sec}$ of a $100-\mathrm{sec}$ period after she returned to within $10 \mathrm{~cm}$ of the target area. Fixes were marked using numbered applicator sticks, and the distance (in $\mathrm{cm}$ ) of each fix was measured with a metric tape measure after the forager was given a food load at the end of each 100 -sec period. In a few cases foragers returned from the nest to the reward site too rapidly for the distances of all fixes to be measured. We deleted from the data set any entries for which we did not have the measurements for all 10 fixes. This procedure gave us a field approximation of one spatial aspect of local search; it is equivalent to our previously cited measurement of average target distance in our laboratory studies. 
To measure changes in search behavior in response to protein and carbohydrate food, a series of eight consecutive rewards of a given food type were offered; target distance was measured after the first, fourth and eighth reward. If a forager showed non-persistent search behavior (i.e., a tendency to show no or little search at the target area) after having collected a food load, she was offered the next reward immediately after the non-persistent search behavior could be identified. Non-persistent search involved traveling straight through the reward site without showing any search in the vicinity of the prior reward and moving at least $50 \mathrm{~cm}$ beyond (see Schmid-Hempel 1984 and Traniello 1988 for a discussion of persistent and non-persistent search). Foragers were always offered food at the same location.

We recorded search patterns in response to each food type before and after the mating flight, which occurred during the first week of July, to determine if colony requirements for carbohydrate and protein food influenced the spatial properties of local search behavior of workers. We hypothesized that the increased need for food resources while a reproductive and worker brood was being reared early in the season might correlate with local search behavior.

\section{RESULTS}

Carbohydrate-stimulated local search was consistently characterized by a significantly lower average target distance than protein-stimulated local search, and average target distance did not change as a function of the number of consecutive food loads collected (Table $1 \mathrm{a}, \mathrm{b}$ ). Therefore, local search was spatially centered closer to the site of a prior carbohydrate reward than to the site of a prior protein reward. Because the pattern of search did not vary with a schedule of repeated rewards, foragers did not appear to modify local search in response to either food type. These field results confirm our laboratory findings (Fourcassié and Traniello 1992 a, b).

Average target distance for either food type did not change on a seasonal basis; that is, it was not significantly different before and after the mating flight (Table 1a, b). 
Table $1 \mathrm{a}, \mathrm{b}$. Average target distance of foragers recorded before and after the mating flight. Statistical comparisons were made with a Mann-Whitney U-test. $\mathrm{N}=$ sample size.

a) 1 M Sucrose

\begin{tabular}{cccr} 
Reward Number & $\begin{array}{c}\text { Before Sexuals } \\
\text { Produced (N) }\end{array}$ & $\begin{array}{c}\text { After Sexuals } \\
\text { Produced (N) }\end{array}$ & \multicolumn{1}{c}{$\mathrm{p}$} \\
\hline 1 & $9.3 \pm 5.3(15)$ & $11.1 \pm 4.1(24)$ & .09 \\
4 & $11.2 \pm 5.6(9)$ & $12.4 \pm 9.7(23)$ & 1.00 \\
8 & $9.9 \pm 3.5(8)$ & $10.9 \pm 9.1(23)$ & .31
\end{tabular}

b) Insect Prey

\begin{tabular}{cccc} 
Reward Number & $\begin{array}{c}\text { Before Sexuals } \\
\text { Produced (N) }\end{array}$ & $\begin{array}{c}\text { After Sexuals } \\
\text { Produced (N) }\end{array}$ & p \\
\hline 1 & $24.3 \pm 13.1(17)$ & $28.2 \pm 16.4(14)$ & .61 \\
4 & $28.1 \pm 18.5(14)$ & $24.6 \pm 16.1(12)$ & .56 \\
8 & $22.6 \pm 12.3(14)$ & $25.6 \pm 16.6(11)$ & .72 \\
\hline
\end{tabular}

\section{Discussion}

$F$. schaufussi foragers show different patterns of search orientation in response to carbohydrate and protein food. Orientation during search is one mechanism by which movement may be adjusted according to the distribution of food resources in the environment (Bell 1985, 1991). F. schaufussi foragers appear to have resourcedependent search tactics involving patterns of locomotion that increase the probability that a persistent resource (such as carbohydrate food) will be efficiently relocated. Similarly, the search pattern generated in response to protein food allows a forager to avoid scanning redundantly in the area of a prior find, where the probability of locating additional prey, which are unpredictable in time and space, is low.

The control of search orientation resulting from a forager collecting one resource load and then searching for more appears to involve responses mediated by behavioral predispositions (Traniello 1988; Fourcassié and Traniello, 1992a, b; Fourcassié et al. 1992). Moreover, as shown in the present field study and in the laboratory, short-term experience does not appear to control search pattern (Fourcassié and Traniello, 1992b). Differences in search 
paths elicited in response to carbohydrate and protein food are shown by naive foragers during their first trip outside the nest, and the differences are reflected in path characteristics such as total path length, sinuosity, linearity, turning rate and fractal dimension (Fourcassié and Traniello, 1992a, b; Fourcassié et al. 1992). Local search duration also differs in response to carbohydrate and protein food and the transition from local search to ranging behavior (search behavior characterized by relatively straight locomotion; Jander 1975) during search orientation seems to reflect the distribution pattern of the resources that stimulate search. Giving-up time (the time at which a forager leaves a patch) is longer for carbohydrate food.

Are the local search patterns of foragers influenced by the nutritional requirements of a colony? The lack of a change in search orientation as measured by the positional fixes of foragers collecting food before and after the mating flight suggest that colony requirements for protein and carbohydrate food do not play an important role in directing the search orientation of individuals. A greater demand for protein would be expected before the mating flight (the time from the inception of colony activity in the early spring to the first week of July when alates emerge from nests) because protein is fed to developing sexual and worker larvae. A second, smaller brood of workers is reared after the mating flight, but overall availability of protein food (estimated from sweep samples of arthropods) decreases at this time (Traniello and Beshers, in prep.). The need for protein should be greatest before the mating flight, but carbohydrate might also be required to provide energy utilized in the search for protein. The relationship between colony needs, seasonal changes in resource availability, and total search effort are unclear, but seasonal changes in resource availability and the relative importance of carbohydrate and protein food in the diet do not appear to correlate with the search pattern of individual workers. The question of whether social interactions within a colony and seasonal cycles of resource availability serve as sources of information to guide individual search behavior require further investigation. 


\section{SUMMARY}

Carbohydrate- and protein-stimulated search behaviors differ in the spatial organization of search orientation at the site of a prior food find. These search tactics appear to be based on behavioral predispositions, and are not modified through individual experience. The average distance of a fix marking the position of a forager relative to the site of a prior food find was lower in response to carbohydrate food, and did not change on a seasonal basis. Resource-related search orientation in $F$. schaufussi foragers appears to represent a mechanism controlling efficient search effort.

\section{ACKNOWLEDGEMENTS}

This research was supported by NSF grant BNS 86-16802 and a grant from the Whitehall Foundation to J. Traniello. We thank Dr. Richard Taylor for the use of the field sites at Concord. Michael Fournier was supported by a NSF REU grant supplement.

\section{REFERENCES}

BELL, W. J.

1985. Sources of information controlling motor patterns in arthropod local search orientation. J. Insect Physiol. 31: 837-847.

1991. Searching Behavior: The behavioral ecology of finding resources. Chapman and Hall, New York. 357 pp.

Fourcassié, V. AND Traniello, J. F. A.

1992a. Food-searching behavior in the ant Formica schaufussi (Hymenoptera: Formicidae): response of naive foragers to protein and carbohydrate food. Animal Behaviour, under revision.

1992b. Effects of experience on food-searching behavior in the ant Formica schaufussi (Hymenoptera: Formicidae). J. Insect Behav. in press.

Fourcassié, V., Coughlin, D., And Traniello, J. F. A.

1992. Fractal analysis of search behavior in ants. Naturwissenschaften 79: 87-89.

JANDER, R.

1975. Ecological aspects of spatial orientation. Ann. Rev. Ecol. Syst. 6: 171-188.

SCHMID-HEMPEL, P.

1984. Individually different foraging methods in the desert ant Cataglyphis bicolor (Hymenoptera: Formicidae). Behav. Ecol. Sociobiol. 14: 263-271. 
Traniello, J. F. A.

1988. Variation in foraging behavior among workers of the ant Formica schaufussi: ecological correlates of search behavior and the modification of search pattern. In: Interindividual Behavioral Variability in Social Insects, ed. R. L. Jeanne. pp. 91-112. Westview Press, Boulder CO.

1989. Foraging strategies of ants. Ann. Rev. Entomol. 34: 191-210.

Traniello, J. F. A., Fourcassié, V., and Graham, T.

1991. Search behavior and foraging ecology of the ant Formica schaufussi: colony-level and individual patterns. Ethol. Ecol. Evol. 3: 35-47. 

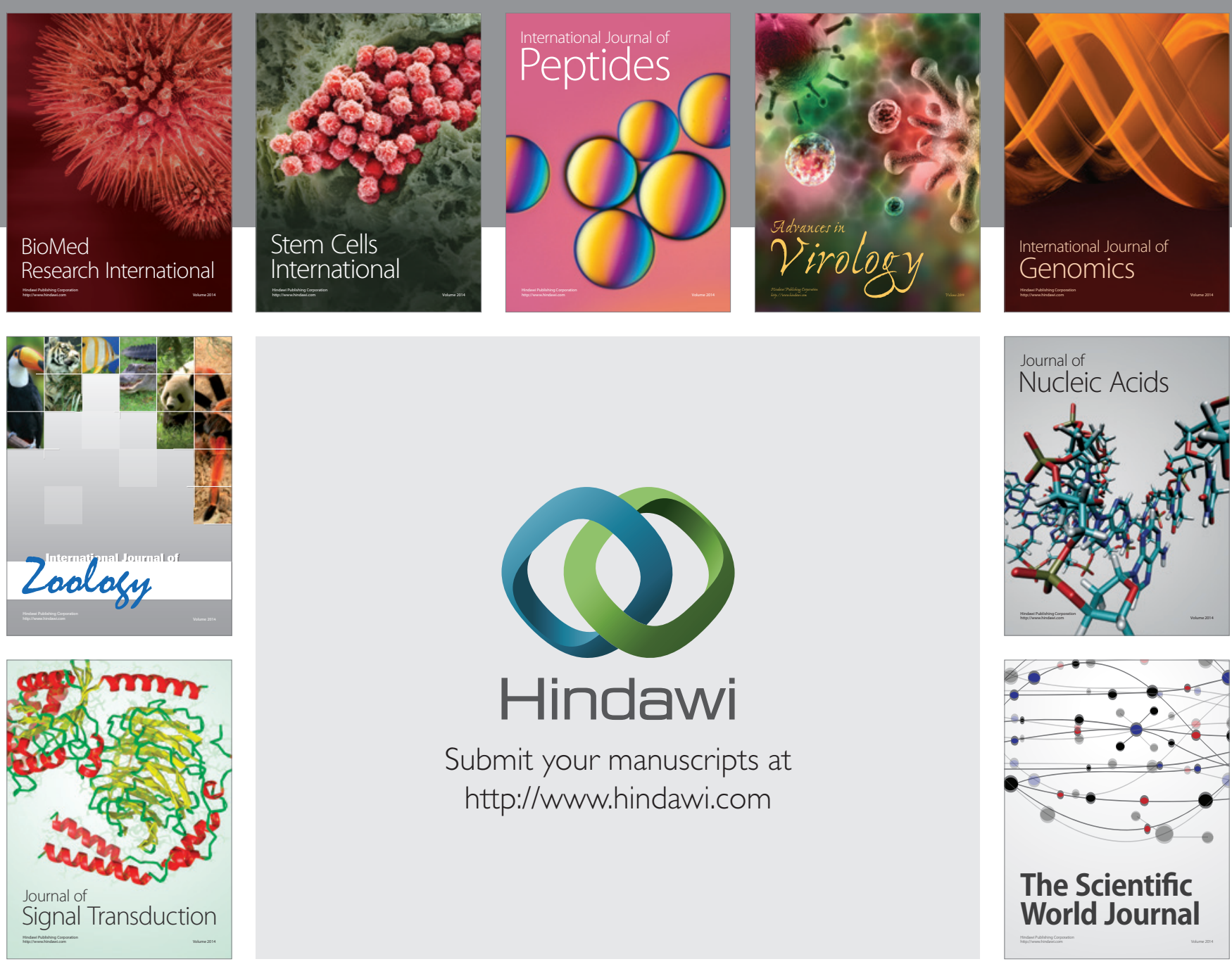

Submit your manuscripts at

http://www.hindawi.com
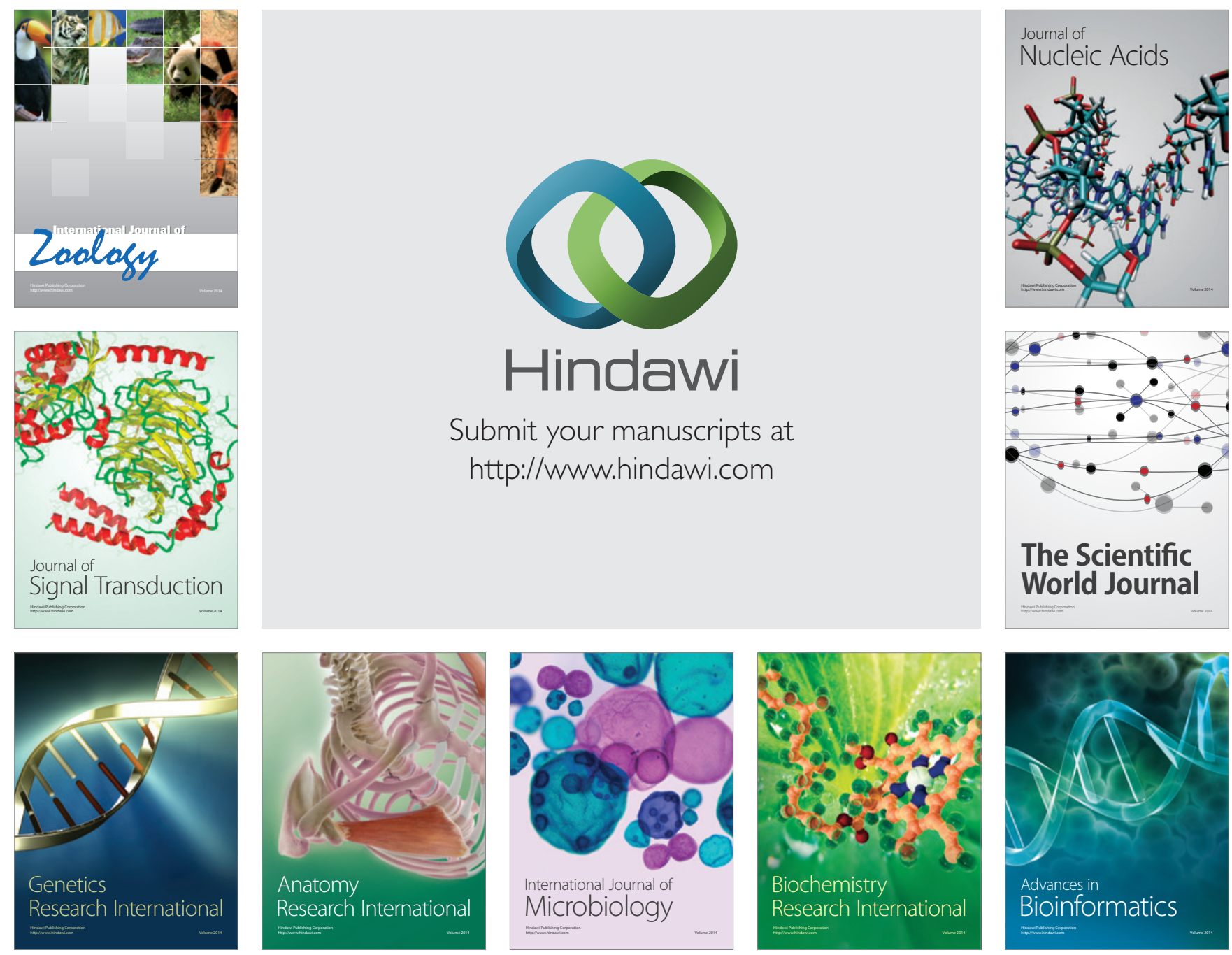

The Scientific World Journal
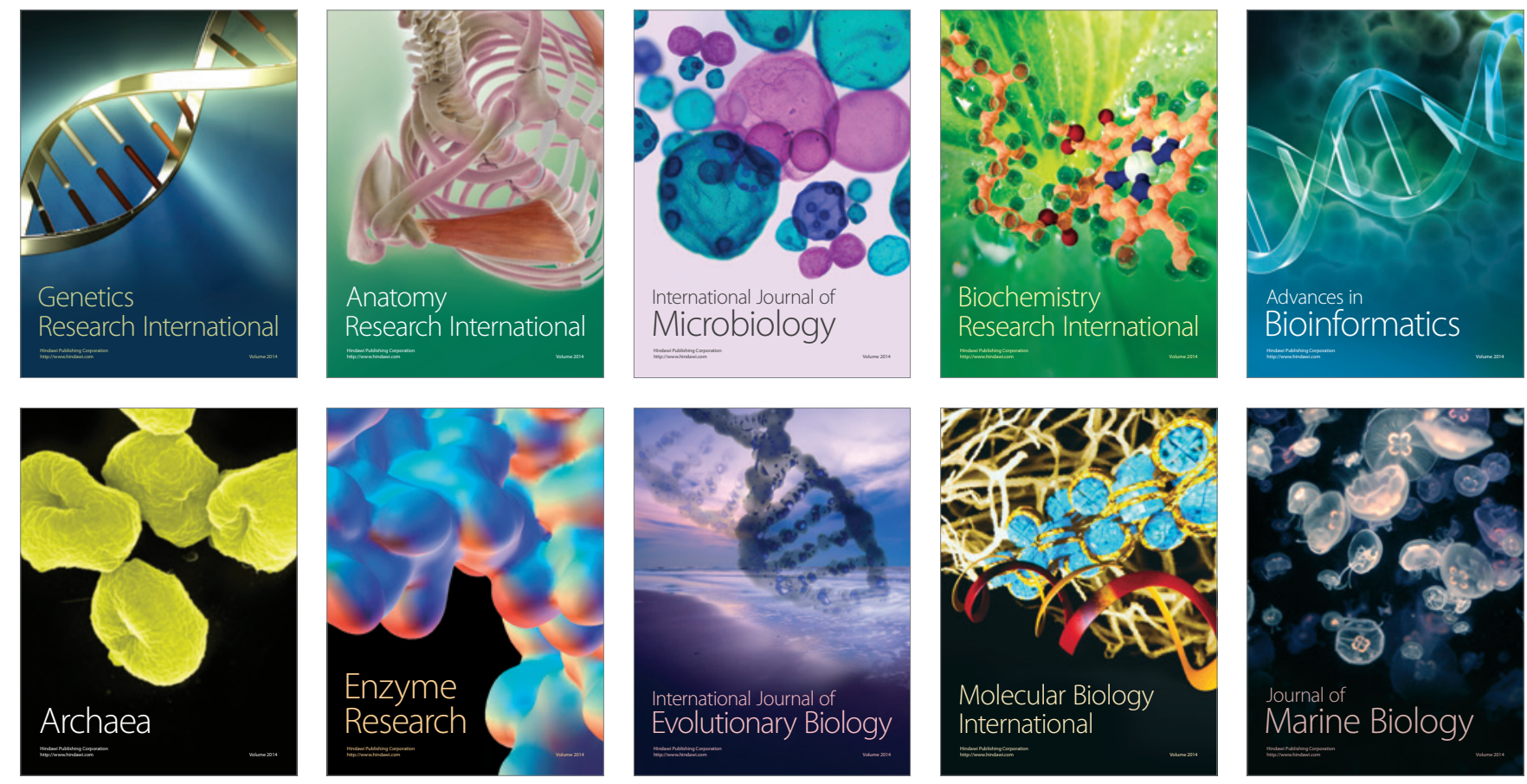